\title{
TREATMENT OF LEAD CONTAMINATED WASTE SLUDGE USING THE WILD RADISH VEGETABLE SPECIES Raphanus raphanistrum
}

\author{
TRATAMIENTO DE LODOS CONTAMINADOS CON PLOMO UTILIZANDO LA \\ ESPECIE VEGETAL Raphanus raphanistrum
}

\section{Marco Pino-Vallejo ${ }^{(1,2) *}$; Ana Román Latorre ${ }^{(1)}$; Margarita Haro Robayo ${ }^{(1)}$; Ana Andrade Orozco ${ }^{(3)}$; Nelly Perugachi Cahueñas ${ }^{(4)}$ \\ (I) Universidad de las Fuerzas Armadas, Sangolqui - Ecuador.}

(2) Instituto Superior Tecnológico República Federal de Alemania, Riobamba - Ecuador.

(3) Universidad Nacional de Chimborazo, Riobamba - Ecuador.

(4) Escuela Superior Politécnica de Chimborazo, Riobamba - Ecuador.

Email:marcopinovallejo@hotmail.com

https://doi.org/10.33789/talentos.8.2.155

\begin{abstract}
Sludge generated in the treatment of urban wastewater must be properly treated as it may contain concentrations of heavy metals or the presence of pathogenic microorganisms. The wastewater treatment plant in the main parish of Penipe, Chimborazo province, Ecuador, consists of an Imhoff tank in whose sedimentation chambers the waste sludge from physical treatment is digested under anaerobic conditions. The sludge is discharged into an open-air drying bed and does not receive treatment to stabilize it. Laboratory analysis determined that the sludge contains $24.23 \mathrm{mg} . \mathrm{kg}^{-1}$ of lead and is considered a potentially hazardous waste. The aim of the research is to treat the contaminated sludge by means of phytoextraction. The plant species known as wild radish (Raphanus raphanistrum) was sown in the residual mud and the treatment was biomonitoring for 91 days. Mud samples were taken every 15 days and by laboratory analysis a decrease in lead concentration was identified, identifying a root absorption efficiency of $16.40 \%$.
\end{abstract}

Keywords: Waste Sludge, Lead, Phytoextraction, Raphanus raphanistrum

Recibido: 09 de septiembre de 2021

Online: 09 de diciembre de 2021
Aceptado: 08 de dicembre de 2021

Publicación: 01 de julio de 2021

Publicado como artículo científico en la Revista de Investigación Talentos 8 (2), 68-77 
Resumen: Los lodos generados en el tratamiento de aguas residuales urbanas deben ser tratados de manera adecuada debido a que pueden contener concentración de metales pesados o presencia de microorganismos patógenos. La planta de tratamiento de las aguas residuales de la parroquia Matriz del cantón Penipe, jurisdicción de la provincia de Chimborazo, Ecuador, está compuesta de un tanque Imhoff en cuyas cámaras de sedimentación se digieren en condiciones anaerobias los lodos residuales producto del tratamiento físico. El lodo es descargado en un lecho de secado a cielo abierto y no recibe tratamiento para estabilizarlo. Los análisis de laboratorio determinaron que los lodos contienen $24.23 \mathrm{mg}_{\mathrm{kg}} \mathrm{kg}^{-1}$ de plomo considerándose como residuos potencialmente peligrosos. El objetivo de la investigación es tratar el lodo contaminado mediante fitoextracción. Se sembró en el lodo residual la especie vegetal conocida como rábano silvestre (Raphanus raphanistrum) y se biomonitoreo el tratamiento por 91 días. Se tomó cada 15 días muestras de lodo y mediante análisis de laboratorio se identificó disminución en la concentración de plomo, identificándose una eficiencia de absorción radicular de $16.40 \%$.

Palabras Claves: Lodos residuales, Plomo, Fitorremediación, Raphanus raphanistrum

\section{INTRODUCTION}

The final disposal of sludge from wastewater treatment involves considerable economic costs, depending on the technique applied, i.e., the installation of stabilizing reactors or dehydration and incineration systems (Mahamud López, Gutiérrez Lavín, Sastre Andrés, 1996). The volume of sludge produced depends on the characteristics of the wastewater, the degree of pre-treatment, the sedimentation time, the solids density, the moisture content, the type of sludge removal equipment or method, and the frequency of sludge removal (Oropeza García, 2006).

The techniques most used to treat sewage sludge are a) mechanized dehydration, which reduces $20 \%$ of the sludge volume but does not reduce the concentration of heavy metals or pathogenic microorganisms, and b) incineration using burners, which reduces the volume by $80 \%$ and eliminates toxic organic compounds; destroys bacteria but generates dioxins and furans that pollute the air and requires high operating costs (Cardoso, 2003). Environmental problems arise when sludge is deliberately dumped into drains, discharged into surface water bodies, disposed of in landfills or incinerated without adequate safeguards, which cause environmental pollution (Paredes Concepción, 2014; Galvis Toro y Rivera Guerrero, 2013). There are cases in which sludge is deposited on farmland as compost, assuming that it contains nitrifying organic loads, but in this type of substrates inorganic elements such as heavy metals may be present, which can enter the food chain by bioaccumulation.

In recent years, biological methods to stabilize waste sludge have emerged as a viable, efficient, and low-cost alternative (Castillo Sánchez, Balarezo Saltos, Vinces Obando 
y Zambrano Rizo, 2020). Phytoextraction refers to the potential of some plants to absorb soil pollutants through their roots, promoting a long-term cleaning of the soil or sludge (Bhargava et al. 2012).

The Raphanus raphanistrum plant of the Cruciferae Family (Brassicaceae) of the genus Raphanus, is known as radish, horseradish, or wild radish (Pandolfo, 2016). The Raphanus raphanistrum plant is a field herb with more than 10 centimeters high, rough leaves, highly divided with irregular lobes where the apical can be the largest. The flowers are whitish with well-marked violet veins, it develops strangulations between each of the seeds giving it a particular shape and blooms almost all year round (Àrea de Botánica Departamento de Biología Universitat de les Illes Balears, 2019).

Since 2012, the main parish of Penipe has had a wastewater treatment system consisting of an Imhoff tank designed to treat a wastewater flow of $530 \mathrm{~m}^{3}$.day ${ }^{-1}$. The purpose of this treatment is to digest the sludge in anaerobic conditions and to collect cream (LozanoRivas, 2010). The tank is rectangular in shape and consists of 2 sedimentation chambers, 2 sludge digestion chambers, 2 cream chambers, 4 valves connected to pipes to discharge the sludge to an open-air drying.

The Imhoff tank in its primary treatment separates by physical means the sedimentable solids (sludge), as well as the floating substances such as grease, fibers, etc. (Lombeida Rojas, 2017). The by-products of wastewater treatment are treated ater and waste sludge (Llagostera \& Salgot, 2005). Sludge is the by-product with the largest volume, so its handling, transport, treatment, use, and final disposal are more complex (Metcalf \& Eddy, 2004). Sludge is characterized by the presence of pathogens, organic and inorganic matter, and moisture (Gualoto Gualoto, 2016). Adequate sludge treatment consists of thickening, conditioning, stabilization, dehydration, and final disposal (VicencioDe la Rosa, Pérez-López, Medina-Herrera y Martínez-Prado, 2011).

In the drying bed of the wastewater treatment plant of the main parish of Penipe canton between the period 2012 - 2018, about 408.00 $\mathrm{m}^{3}$ of wasted sludge has been discharged, which has been subjected to laboratory analysis determining that it contains An average concentration of $24.23 \mathrm{mg} \cdot \mathrm{kg}^{-1}$ of lead. The waste sludge remains in the drying beds and is not treated for stabilization and final disposal. Lead is a heavy metal that does not usually degrade, so it can remain in soil, water and air (Valdés y Cabrera, 1999). Contaminants in soils and sediments as trace elements can be found in six different forms: particulate, liquid films, adsorbed, dissolved in pore interstitial water, and solid phases in pores (Rulkens, Grotenhuis \& Tichy, 1995). The retained metal found in the soil will have relative availability by plants and thus incorporation into their tissue (KabataPendias, 1995).

The aim of the research is to treat waste sludge by phytorextraction using the Raphanus raphanistrun plant and to determine its capacity to remove lead by root absorption. 


\section{MATERIAL AND METHODS}

Plant growing process: The Raphanus raphanistrum plant is a native species of the study area. The seeds were collected in the community of Nabuzo (17M 773660 East, 9828006 South, altitude 2477 m.a.s.l.), in the Penipe canton. For the research, the seeds were cultivated up to the seedling stage.

Waste sludge sample collection: Lead is a metal that is difficult to mobilize and has no biological value, making it dangerous (Granda, 2011). The heavy metals mobility is very low, remaining accumulated in the first centimeters of the soil, being leached to the lower horizons in very small quantities (Galán y Romero, 2008).

When the contamination area is in the rectangle shape, the number of samples and distribution will be one sample per each short wall, two per each long wall and two at the bottom for a total of 8 samples (Guía para muestreo de suelos Decreto Supremo $\mathrm{N}^{\circ}$ 002-2013-MINAM).

The Penipe wastewater treatment sludge drying bed is $20.00 \mathrm{~m}$ long, $20.50 \mathrm{~m}$ wide and $0.50 \mathrm{~m}$ deep. Due to its rectangular shape, 8 sampling points (SP) were located, as shown in Figure 1.

Figure I. Sample collection method

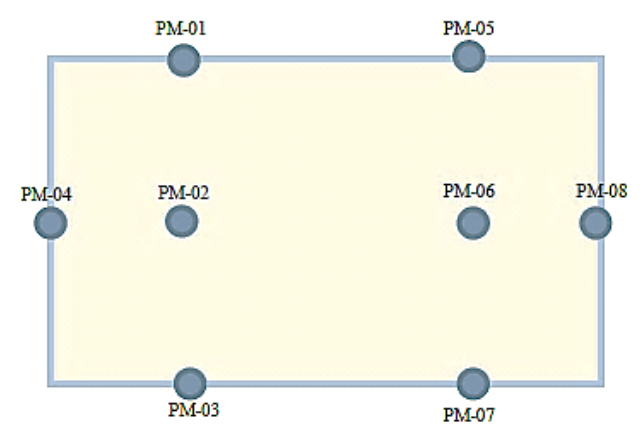

Sample volume: When working with large containers, or with sludge obtained from continuous procedures, samples must be taken at different points, which will then be combined to obtain a composite sample (Satti, 2015). To obtain a homogeneous sample at each sampling point, $0.30 \mathrm{~m}$ was excavated, and $0.44 \mathrm{~kg}$ of dehydrated waste sludge (sandy texture) was collected, after which the 8 samples were mixed to form a composite sample with a total weight of $3.50 \mathrm{~kg}$.

Experimental units: For the phytoextraction process control, the previously grown plants were placed in glass experimental units with a capacity of $0.60 \mathrm{~m}^{3}$. As illustrated in Figure 1, in the Biomonitoring Unit for lead contaminated sludge (BU-PbCS), the plant was sown in $3.50 \mathrm{~kg}$ of composite sample and in the Common Soil Biomonitoring Unit (CS-BU) the plant was sown in $3.50 \mathrm{~kg}$ of common soil and served as a pilot to compare the development of the two plants.

Figure II. Raphanus raphanistrum transplanting

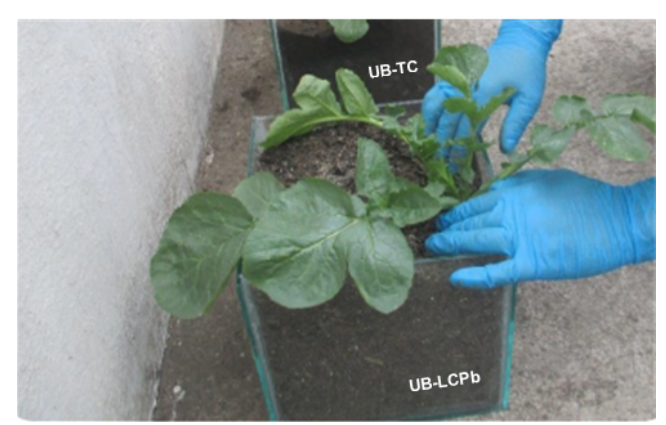

The experimental units were placed in the open air (Humidity: $89 \%$, Max. temp. $20^{\circ} \mathrm{C}$, Min. temp. $7^{\circ} \mathrm{C}$ ), and irrigated with $250 \mathrm{ml}$ of water every two days.

Biomonitoring: This technique, based on the reaction and sensitivity of different living 
organisms to various pollutants present in the environment, can be performed by two methods: a) study of the effects on the indicator organism, and b) sampling of the target environment and laboratory analysis (Biomonitoreo para la limpieza del ambiente, 2007; Segretin, 2010). For the purposes of the research, both methods were applied.

Lead removal: Every fifteen days, $100 \mathrm{mg}$ of sludge samples were taken from the $\mathrm{BU}-\mathrm{PbCS}$ what is the required amount for laboratory analysis to determine variations in lead concentrations. At the same time, sludge $\mathrm{pH}$ measurements were taken, since in the absorption process, the lower the $\mathrm{pH}$ (acid soils), the greater the solubility of the metals, and therefore the greater the mobility
(Hernández, Rodríguez y Oviedo, 2019). The sludge samples from the BU-PbCS were analyzed at the Centro de Servicios Técnicos y Transferencia Tecnológica Ambiental CESTTA. The EPA 200.7 / EPA 3015a ICP method was used to determine the lead parameter and the EPA 9045 D method was used to determine the $\mathrm{pH}$.

To calculate the lead removal percentage, the input concentration and the output concentration obtained from the laboratory results were considered using the equation (Chicón, 2000):

Ec. 1.

Removal $\%=\frac{\text { Input concentration }- \text { Output concentration }}{\text { Input concentration }} * 100$

\section{RESULTS AND DISCUSSION}

Study of the effects on the indicator organism: The plants were monitored for 3 months, during which time they completed their life cycle, as shown in Table I.

Table I. Plant development in the experimental units

\begin{tabular}{cll}
\hline Day & \multicolumn{1}{c}{ BU-PbCS } & \multicolumn{1}{c}{ CS-BU } \\
\hline 1 & Beginning of monitoring. & Beginning of monitoring. \\
7 & There are no variations in plants. & There are no variations in plants. \\
14 & Plants develop leaves and flowers. & Plants develop leaves and flowers. \\
21 & Short stems. & Long stems. \\
28 & Fewer leaves. & More leaves. \\
35 & No significant variations. & No significant variations. \\
42 & Stems with 4 branches. . & Stems with 5 branches. \\
49 & Narrow leaves. & Wide leaves. \\
56 & No significant variations. & No significant variations. \\
63 & Stems with 5 branches. & Stems with 8 branches. \\
70 & Few flowers. & Abundant flowers. \\
77 & Few green segments in the plant & Intense yellow color in the plant structure. \\
& structure. & \\
84 & Plants begin to dry out. & Plants begin to dry out. \\
91 & Plants complete their life cycle. & Plants complete their life cycle. \\
\hline
\end{tabular}


The development of the plants has marked differences from day 21 onwards, the plants planted in the lead-contaminated sludge have less development in leaves and flowers as opposed to the pilot plant. The plant completes its life cycle, which indicates that lead is easily adsorbed and is not toxic to the plant species.

In the study "The effect of lead on Allium cepa", it is concluded that lead reduces root growth and the frequency of mitotic cells and increases the frequency of aberrant cells (Lerda, 1992). In Raphanus raphanistrum species, inhibition of root elongation and leaf and flower development was observed. The Raphanus raphanistrum plant species, like Allium cepa, are vascular plants of different families, but share the same characteristic, being slightly tolerant to lead.

The different responses of vascular plants can be attributed to genetic and physiological factors (Calow, 1993). In the "Comparative study of trace element accumulation in Brassicaceae plant species with phytoremediation potential", the potential for phytoextraction of metals is evaluated with 4 species of the Brassicaceae family, concluding that the metal content in plant organs varies with the species: a) Brassica campestris (wild turnip) has the potential for simultaneous phytoextraction of zinc, cadmium and copper, b) Rorippa palustris (water radish) has a potential for zinc and cadmium, whereas c) Sinapis arvensis (field mustard) and d) Thlaspi arvense (Bolivian zurrón) are suitable for the phytostabilization of zinc and lead. (Drozdova, Alekseeva Popovaa, Dorofeyeva, Bech, Belyaeva \&
Roca, 2021). The laboratory results obtained in the current study determine that the plant species Raphanus raphanistrum (wild radish) has potential for the phytoextraction of lead.

Sampling of the target environment and laboratory analysis: To determine the lead phytoextraction process using the plant species Raphanus raphanistrum, seven samples each fifteen days were taken from the sludge of the BU-PbCS.

Table II. Laboratory analysis during treatment

\begin{tabular}{cccc}
\hline Monitoring Day & Sample & $\begin{array}{c}\text { Concentration } \\
\left.\text { Pb (mg.kg } \mathbf{~}^{-1}\right)\end{array}$ & $\mathbf{p H}$ \\
\hline 1 & 1 & 24.23 & 7.64 \\
15 & 2 & 22.92 & 7.49 \\
30 & 3 & 20.51 & 6.38 \\
45 & 4 & 22.08 & 6.34 \\
60 & 5 & 21.49 & 7.09 \\
75 & 6 & 19.16 & 7.54 \\
90 & 7 & 20.60 & 7.13 \\
\hline
\end{tabular}

Source: Authors

In Table II, the laboratory results indicate that lead concentrations do not stabilize and fluctuate, as does the $\mathrm{pH}$, which at the beginning is slightly alkaline and tends to acidify slightly in samples 3 and 4, and then recovers its initial condition. These values represent a relationship between the relative mobility of the heavy metal and its availability, since the plants receive $250 \mathrm{ml}$ of water every two days, the water potential influences the lead soluble ions and for this reason they are not conditioned to the $\mathrm{pH}$ of the substrate.

Lead removal rate: Using the percentage removal equation, the initial concentration was compared with the results of the laboratory samples. 
Table III. Lead phytoextraction efficiency

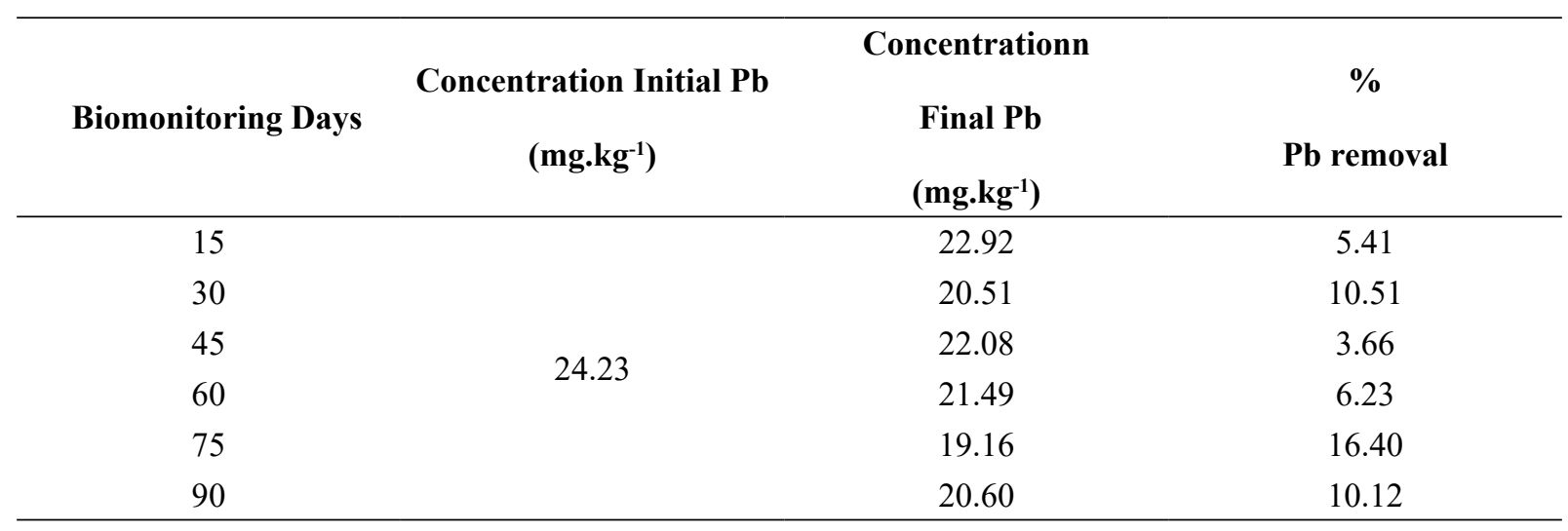

Source: Authors

In Table III, the removal percentages show a decrease in the concentration of the heavy metal, the phytoextraction process with the plant species Raphanus raphanistrum has a maximum efficiency of $16.40 \%$.

\section{CONCLUSIONS}

Plant species of Brassicaceae family have the potential to adsorb heavy metals.

The Raphanus raphanistrum plant species can be planted directly into a lead-contaminated substrate.

The water potential when watering the plant influences the relative mobility of lead and its availability.

The Raphanus raphanistrum plant species used in the lead phytoextraction process is efficient but is not considered to be a hyperaccumulator.

\section{REFERENCES}

Área de Botánica Departamento de Biología Universitat de les Illes Balears. (2019). Raphanus raphanistrum L. subsp. landra (Moretti ex DC.) Bonnier \& Layens. Disponible en: http:// herbarivirtual.uib.es/es/general/607/ especie/raphanus-raphanistrum-1-subspraphanistrum

Biomonitoreo para la limpieza del ambiente. (2007). Consejo Argentino para la información y el Desarrollo de la Biotecnología. Edición No.88; 2007. Disponible en: https://www. porquebiotecnologia.com.ar/Cuadernos/ El_Cuaderno_88.pdf

Bhargava et al. (2012). Approaches for enhanced phytoextraction of heavy metals. Journal of Environtmental Management 105, 103-120.

Cardoso, L.; et al. (2003). Manejo de lodos residuales en México. En: XXVII Congreso Interamericano de Ingeniería Sanitaria y Ambiental. (3-8, diciembre: Brasil). Memorias. Puerto Alegre, Brasil. 
p. 1-7.

Castillo Sánchez J, Balarezo Saltos L, Vinces Obando M, Zambrano Rizo H. (2020). Alternativas en la estabilización de lodos provenientes de plantas de tratamiento de aguas residuales. Revista RIEMAT; 5 (1): 23-7.

Chicón L. (2000). Especiación de metales pesados en lodos de aguas residuales de origen urbano y aplicación de lodos digeridos como mejoradores de suelos [Internet]. Málaga: Trabajo de investigación del Programa de Doctorado en Ingeniería Ambiental de la Universidad de Málaga. Disponible en: https://www. pilcomayo.net/media/uploads/biblioteca/ libro_902_MA-271.pdf

Drozdova I, Alekseeva Popovaa N, Dorofeyeva V, Bech J, Belyaeva A, Roca N. A. (2019). Comparative study of the accumulation of trace elements in Brassicaceae plant species with phytoremediation potential. Applied Geochemistry. Disponible en: https://doi. org/10.1016/j.apgeochem.2019.104377

Galán, E y Romero, A. (2008). Contaminación de suelos por metales pesados. Revista de la sociedad española de mineralogía. Recuperado de: http:/www.ehu.eus/sem/ macla_pdf/macla10/Macla10_48.pdf

Galvis Toro J; Rivera Guerrero X. (2013). Caracterización fisicoquímica $\mathrm{y}$ microbiológica de los lodos presentes en la planta de tratamiento de aguas residuales industriales (PTARI) de la empresa Jugos Hit de la ciudad de Pereira
[Tesis tecnología]. Pereira: Universidad Tecnológica de Pereira. Recuperado a partir de:

http://repositorio.utp.edu.co/dspace/bitstream/handle/11059/3898/62839G182.pd$\mathrm{f}$ ?sequence $=1$ \&isAllowed $=\mathrm{y}$

Gualoto Gualoto G. (2016). Propuesta de gestión de lodos residuales municipales. Caso de estudio: planta de tratamiento de agua residual de la parroquia rural de Nono. Quito: Politécnica Nacional. Recuperado de: https://bibdigital.epn.edu. ec/bitstream/15000/17066/1/CD-7650.pdf

Guía para muestreo de suelos Decreto Supremo No 002-2013-MINAM. (2014). Estándares de Calidad Ambiental (ECA) para Suelo [en línea]. Ciudad de Lima: / Ministerio del Ambiente. Dirección General de CalidadAmbienta; 2014 [citado el 15 enero del 2021]. Disponible en: https://www.minam.gob.pe/wp-content/ uploads/2014/04/GUIA-MUESTREOSUELO_MINAM1.pdf

Granda, J. (2011). Evaluación de la técnica de electrorremediación de suelos contaminados por metales pesados. Recuperado de: http://dspace.utpl.edu. ec/bitstream/123456789/1562/3/Granda_ Laso_Jorge_Francisco.pdf

Hernández, C; Rodríguez, C y Oviedo, R. (2019). Evaluación de la efectividad en la recuperación de aguas contaminadas por hidrocarburos, mediante la técnica de Fitorremediación utilizando Pasto Vetiver. 17th LACCEI International MultiConference for Engineering, Education, 
and Technology: "Industry, Innovation, And Infrastructure for Sustainable Cities and Communities", 24-26 July 2019, Jamaica. Disponible en: http://repositorio. uts.edu.co: $8080 / \mathrm{xmlui} /$ bitstream/ handle/123456789/1316/Articulo\%20 $\% 20$-\%20Fitorremediaci\%C3\%B3n. pdf? sequence $=1 \&$ isAllowed $=\mathrm{y}$

Kabata-Pendias, A. (1995): Agricultural pro problems related to excessive trace metal contents of soils. In "Heavy Metals", W. Salomons, U. Förstner \& P. Mader, eds. Springer-Verlag, Berlin, 3-18.

Lerda, D. (1992). The effect of lead on Allium cepa L. Mutation Research, 281:89-92.

Calow, P. (1993). Handbook of ecotoxicology. Vol. I. 478 p. Blackwell Science Ltd., London, England.

Llagostera, R. \& Salgot, M. (2005). Gestión Integrada de Lodos (Fangos) de Depuradora. En: Tratamiento, disposición y aprovechamiento de lodos residuales. Instituto Mexicano de Tecnología del Agua (IMTA), México.

Lombeida Rojas L. (2017). Diseño de una planta de tratamiento de aguas residuales para una empresa de curtiembre [Tesis pregrado]. Quito: Universidad Central del Ecuador 2017. Recuperado a partir de: http://www.dspace.uce.edu. ec/bitstream/25000/9724/1/T-UCE0008-Q001-2017.pdf

Lozano-Rivas, W. (2012). Diseño de plantas de tratamiento de aguas residuales. Bogotá. Colombia. Disponible en: https://www. researchgate.net/publication/298354134
Diseno_de_Plantas_de_Tratamiento_de_ Aguas_Residuales

Mahamud López M, Gutiérrez Lavín A, Sastre Andrés H. (1996). Biosólidos generados en la depuración de aguas; 3(2): 47-7. Disponible en: https://doi.org/10.4995/ ia.1996.2698

Metcalf \& Eddy. (2004). Wastewater engineering: treatment, disposal, and reuse [Internet]. New York: Fourth Edition. Disponible en: https://www.academia. edu/36512973/Wastewater_Engineering _ Treatment_and_Reuse_Fourth_Edition

Oropeza García, N. (2006). Lodos residuales: estabilización y manejo. Revista Caos Conciencia; 1 (1): 51-8. Disponible en: http://dci.uqroo.mx/RevistaCaos/2006_ Vol_1/Num_1/NO_Vol_I_21-30_2006. pdf

Pandolfo C. (2016). Caracterización Agroecológica de poblaciones (Tesis doctoral). Bahía Blanca: Universidad Nacional del Sur. Recuperado de: http://repositoriodigital.uns.edu.ar/ bitstream/123456789/2592/1/Tesis\%20 doctoral\%20Pandolfo.pdf

Paredes Concepción, P. (2014). Producción más limpia y el manejo de efluentes en plantas de harina y aceite de pescado. Industrial Data; 17 (2): 72-0. Disponible en: $\quad \mathrm{https}: / /$ revistasinvestigacion. unmsm.edu.pe/index.php/idata/article/ view/12050/10766.

Rulkens, W.H., Grotenhuis, J.T.C. \& Tichy, R. (1995): Methods for cleaning contaminated soils and sediments. In "Heavy Metals", 
W. Salomons, U. Förstner \& P. Mader, eds. Springer-Verlag, Berlin, 165-191.

Satti P. (2015). Métodos de análisis de lodos, tratamiento, disposición y usos [Internet]. Argentina: Grupo de suelos. Recuperado de: http://www.cofes.org.ar/descargas/ relas/4_jornada/1_Curso_Metodos_Dra_ Patricia_Satti_COFES-1.pdf.

Segretin M. (2010). Biomonitoreo ambiental y tratamiento de efluentes. Consejo Argentino para la información y el Desarrollo de la Biotecnología ArgenBio. Recuperado de: https://studylib.es/ doc/4188639/biomonitoreo-ambiental-ytratamiento-de-efluentes

Valdés F, Cabrera V. (1999). En Defensa del Ambiente, A.C: La contaminación por metales pesados en Torreón, Coahuila, México [Internet]. Primera edición. Texas. Center for Policy Studies. Disponible en: https://libapps-eu.s3.amazonaws. com/accounts/59017/images/Libguidevancouver-ejemplo-libro-Internet.jpg

Vicencio-De la Rosa M, Pérez-López M, Medina-Herrera E, Martínez-Prado M. (2011) Producción de composta y vermicomposta a partir de los lodos de la planta de tratamiento de aguas residuales de un rastro. Rev. Int. Contam. Ambient ;27(3): 263. Disponible en: http://www. scielo.org.mx/pdf/rica/v27n3/v27n3a11. pdf 